Maurer School of Law: Indiana University Digital Repository@ Maurer Law

1982

\title{
Mass Asylum and Human Rights in American Foreign Policy
}

John Scanlan

Indiana University Maurer School of Law, scanlan@indiana.edu

G. D. Loescher

University of Notre Dame

Follow this and additional works at: http://www.repository.law.indiana.edu/facpub

Part of the Human Rights Law Commons, and the International Humanitarian Law Commons

\section{Recommended Citation}

Scanlan, John and Loescher, G. D., "Mass Asylum and Human Rights in American Foreign Policy" (1982). Articles by Maurer Faculty. 2496.

http://www.repository.law.indiana.edu/facpub/2496 


\title{
Mass Asylum and Human Rights in American Foreign Policy
}

\author{
JOHN A. SCANLAN \\ G. D. LOESCHER
}

From 1948, when the United States began admitting European displaced persons, until 1980, when the so-called Cuban freedom flotilla arrived in Florida, the standard method of admitting refugees to this country was first to screen them abroad and then to permit them entry according to their place on rank-order waiting lists. Although nearly 2 million aliens entered the United States in this manner, the political problems associated with large-scale refugee movements, and with applications from individuals fleeing repressive regimes diplomatically tied to the United States, were minimized. In this way, U.S. officials could regulate the flow of refugees to avoid unacceptable levels of domestic backlash and to keep international embarrassments to a minimum. It was possible, in other words, to maintain without much difficulty a refugee admissions system almost entirely independent of U.S. immigration law, under the direct control of the executive rather than the legislative branch, and dedicated to a few consistent, but limited, foreign-policy ends.

Those ends were not divorced from humanitarian considerations, but neither were they dominated by them. The statutory definition of refugee adopted in 1965, which - with the exception of certain victims "of catastrophic natural calamity"-included only those fleeing persecution "from a Communistdominated country or area, or from any country within the general area of the Middle East," ${ }^{1}$ reflected a cold war policy choice that directed the nation's

18 U.S.C. Sec. 1153(a)(7), Immigration and Nationality Act [I.N.A.] Sec. 203(a)(7) (repealed).

JOHN A. SCANLAN is assistant director of the Center for Civil and Human Rights at the Notre Dame Law School. G.D. LOESCHER, assistant professor in the Department of Government and International Studies at the University of Notre Dame, is coeditor of Human Rights and American Foreign Policy. Both served as consultants to the Select Commission on Immigration and Refugee Policy and are currently at work on a book about the history of American refugee admissions policy, funded by the Ford Foundation. 
generosity toward the victims of many, but certainly not all, of the most severe refugee-producing situations of the last thirty years. Of the millions of African refugees displaced by intertribal terrorism, famine, and war since 1960, only a few thousand ever reached the United States. No equivalent to the "open arms" extended to Cubans fleeing Castro from 1961 to April 1980 was ever extended to Chileans fleeing Pinochet, Haitians fleeing Duvalier, or those fleeing the current bloodshed in El Salvador. The admission of some 400,000 displaced persons from post-World War II Europe, 35,000 Hungarians from Austria in 1957-1958, and nearly 500,000 Indochinese from Thailand, Malaysia, and the Philippines from 1975 to 1980 had as a common theme American concern over the destabilizing effect of large refugee populations in parts of the world deemed vital for national security. The admission of over 800,000 Cubans from 1961 to 1 April 1980 and of 50,000 Soviet Jews from 1973 to the present was predicated not only on the existence of political persecution abroad and on the presence of vocal pressure groups in the United States, but also on continuing anti-Communist sentiment in the foreign-policy community and a continued interest in seeing those opposed to communism "vote with their feet."

Nothing the Reagan administration has done or said suggests any dissatisfaction with these traditional ends of American refugee admissions policy. Yet two events in the spring of 1980 affecting the flow of refugees into the United States, and the nation's ability to control that flow, have substantially altered the context in which admissions decisions must be made. The first of these events was the passage of a new Refugee Act in March; the second was the beginning of a mass asylum crisis in April, when the Cuban "freedom flotilla" began. Together, they have created practical and political difficulties that cannot be resolved unless the nation turns more of its attention to the refugee problem in this hemisphere, responds to that problem in a manner that places predominant emphasis on human rights rather than on ideology, and enlists more multilateral and bilateral cooperation in an attempt both to minimize the number of refugees and more equitably resettle those who cannot be repatriated.

\section{The Effect of the Refugee Act of 1980}

The new Refugee Act incorporates into domestic law for the first time a definition that is not ideologically or geographically limited. Under the new law, any person from any part of the world is eligible for refugee status, provided that he or she can demonstrate a "well-founded fear of persecution on account of race, religion, nationality, membership in a particular social group, or political opinion." 2 The new law, of course, is subject to different interpretations: "Merely because an individual or group of refugees comes within the definition will not guarantee resettlement in the United States. . . . the new definition does not create a new and expanded means of entry, but instead regularizes and for-

${ }^{2}$ Section 201(a), Refugee Act of 1980, 94 Stat. 101, adding 8 U.S.C. Sec. 1101(a)(42), I.N.A. Sec. 101(a)(42). 
malizes the policies and the practices that have been followed in recent years."3 For individuals outside of the United States seeking refuge, this analysis of the law is substantially correct. For those reaching the borders of the United States before seeking refuge, however, the new definition does appear to provide "a new and expanded means of entry." The new Refugee Act affords protection for the first time to many fleeing right-wing repression in this hemisphere and expands upon the protections traditionally afforded to refugees seeking withholding of deportation. ${ }^{4}$ The effect of these changes is to prevent the United States from expelling or returning any alien who, having reached the United States, can demonstrate he or she fits within the new refugee definition.

When Congress passed the new Refugee Act, it apparently believed that no more than 5,000 aliens per year would enter the United States with potentially valid asylum claims. Given the fact that nearly 20,000 such claims were pending in November, 1979, and that at least as many potential claims were being administratively bypassed at the time the Refugee Act was enacted, such an estimate may have been overly optimistic. ${ }^{5}$ At any rate, it became quickly inoperative in April 1980 when the first wave of the "freedom flotilla," eventually bringing 130,000 Cubans to Florida in a five-month period, hit American shores. By the end of 1980, these Cubans had been joined by over 11,000 Haitian "boat people" and by an indeterminate number of Ethiopians, Nicaraguans, Iranians, and Salvadorans seeking political asylum. Perhaps 150,000 to 160,000 aliens entered the United States in 1980 with potential asylum claims.

The bureaucracies charged with regulating refugee flow were overwhelmed by this massive influx. The Immigration and Naturalization Service (INS) lacked the personnel to interview expeditiously each person seeking asylum, much less to evaluate each applicant's claim properly. The Department of State, charged with issuing an "advisory opinion" as to the probable good faith of each applicant's "well-founded fear," was even more understaffed. 6 The Carter administration therefore sidestepped the question of which applicants would be granted asylum by creating on 20 June 1980 the temporary status of

${ }^{3}$ U.S., Congress, House, Judiciary Committee, H.R. Report 'no. 608, 96th Cong., 1st sess., November 1979, p. 10.

${ }^{4} 8$ U.S.C. Sec. 1253(h), I.N.A. Sec. 243(h) has been amended to make such withholding mandatory when probable persecution exists. "Excludable aliens," who make up a significant percentage of those seeking asylum, are now also protected by this statutory provision.

${ }^{5}$ Figures on pending asylum claims were obtained from internal INS memoranda that were not available when the new Refugee Act was first reported in 1979. In 1978 and 1979, INS avoided processing most Nicaraguan and Ethiopian asylum claims by granting applicants "extended voluntary departure," thereby permitting continued short-term residence without the immediate threat of deportation. A similar strategy was employed in 1979 and 1980 for Iranians, even though President Carter had proscribed granting them formal "extended voluntary departure" status.

${ }^{6}$ During the height of the Cuban influx, only one State Department officer was assigned full time to handling asylum claims. By August 1980, this number had risen to three. Interviews conducted with State Department and INS officials by G.D. Loescher and John A. Scanlan, 18-19 May and 12-13 August 1980. 
"Cuban/Haitian entrant." Meanwhile, potential asylum-seekers continued to flow into the United States in unprecedented numbers, creating immense difficulties in local host communities and generating a significant backlash in the public and in the press. On the whole, this surge of asylum-seekers into the United States and the governmental and nongovernmental response to that surge constituted the mass asylum crisis of 1980 , the second and most important event challenging the traditional, ideological basis of American refugee admissions policy.

\section{Mass Asylum: A Chronic International Problem}

Brought about because of a large-scale refugee flow not contemplated or addressed by the new Refugee Act, the mass asylum crisis of 1980 has raised fundamental questions about the ability of the United States to regulate the flow of refugees to its borders and about the principles that should govern the regulatory power it does possess. Much of that concern to date has centered on domestic factors, such as those limiting the ability of the government to effectively screen refugees before they enter the mainstream of American society and those contributing to backlash after the refugees are resettled. The Carterappointed Select Commission on Immigration and Refugee Policy, in its Final Report to the Congress and the President, made a number of recommendations that, if adopted, should streamline the processing of massive numbers of asylum claims, aid in the resettlement of those granted asylum, and marginally reduce the number of individuals entering the United States with the hope of remaining indefinitely by dragging out patently nonmeritorious claims. ${ }^{7}$

A more aggressive approach has been taken by the Reagan administration to discourage the flow of refugees seeking asylum. Among the steps already taken have been the stopping of Haitian vessels at sea by the United States Coast Guard and the delivery of their passengers to the Haitian government; the establishment of remote and harsh detention camps for asylum applicants designed to discourage entry and encourage "voluntary" deportation; a new "hard line" toward Cuba; and the introduction of several restrictive immigration bills in Congress. ${ }^{8}$ Yet, there is little consensus among legal scholars, legislators, and immigration authorities about what legal changes can or should be made, and the problems posed by "mass asylum" clearly defy simplistic legal solutions. Aggressive punitive measures directed at asylum-seekers may retard their influx, but will not stem it so long as the underlying reasons for that flow remain intact.

The United States, with the highest standard of living in the Western Hemisphere and a tradition of political freedom, will draw many aliens to its

\footnotetext{
${ }^{7}$ See Select Commission on Immigration and Refugee Policy, U.S. Immigration Policy and the National Interest (Washington, D.C.: Government Printing Office, 1981), pp. 165-76.

${ }^{8}$ As of 15 November 1981, bills had been introduced or proposed in the Senate that would strip asylum-seekers of many of their due-process rights and make them subject to interdiction at sea in violation of customary rules of international law; change the current refugee definition; and put an overall "cap" on immigration that would effectively limit refugee flow.
} 
borders. Determining which are bona fide refugees is an absolutely essential domestic enterprise; yet to the extent that such a determination is made after asylum applicants have reached the United States, and particularly after they have reached the United States in large numbers, it is of limited value. The difficulties the nation faces in returning Cuban criminals to Cuba, or in finding any other country willing to take them, are illustrative of the problems that ensue, as is the long history of American efforts to exclude or deport Haitians not deemed refugees by the INS or by the Department of State. These difficulties are significantly increased whenever an asylum applicant comes from a country where segments of the population suffer severe economic deprivation as a result of governmental policy. Under such circumstances, it is difficult to determine if the government's conduct constitutes a form of "persecution" and, thus, to determine if those entering the United States are "political refugees" or "economic migrants." Although this problem is acute in evaluating the claims of many migrants from the Caribbean basin, it is not due simply to the permissive language of the Refugee Act of 1980. Since 1948, the great majority of "refugees" who have been welcomed to the United States, whether from Western Europe, Vietnam, or Cuba, have entered with mixed political and economic motives. Since 1968, the United States has been obligated by international treaty to determine, on an individual basis, whether particular applicants are in danger of persecution and whether they can be legally returned to their country of origin. ${ }^{9}$

As long as large numbers of undocumented aliens enter the United States with such mixed motives, the government-as recent class-action suits involving Cubans, Haitians, and Salvadorans illustrate ${ }^{10}-$ will find it difficult to summarily turn them away. Yet the current political climate of the region, as well as the standards of conduct of foreign governments that the United States often tacitly supports, makes such large numbers inevitable. The arrival of perhaps 160,000 of these aliens in the United States at the country's borders in 1980 was unprecedented; yet it can be reasonably expected that somewhat smaller, but still very large, numbers of such applicants will arrive in the United States in 1981 and the years following.

The basis for such an expectation is both historical and political. Although most refugees have traditionally entered the United States after being processed abroad, since at least 1965, when "freedom flights" from Cuba were preceded by the arrival of some 2,500 Cubans in boats, some have arrived each year as asylum-seekers. And an increasingly large number have entered the United States illegally from countries in Central America or the Caribbean. An

\footnotetext{
9 Article 33, 1951 Convention Relating to the Status of Refugees, incorporated by 1967 Protocol Relating to the Status of Refugees, 19 U.S.T. 6223, T.I.A.S. 6577(1968).

${ }^{10}$ See, for example, Fernandez-Roque v. Smith, no. C81-1084A (Northern District, Ga.) (20 August 1981) (Cuban internees held in federal prisons ordered released); Haitian Refugee Center v. Civiletti, 503 F. Supp. 442 (Southern District, Fla., 1980) (Haitian deportation orders set aside). A campaign has recently been initiated by several public-interest law groups to bring similar actions on behalf of Salvadorans detained in the Southwest.
} 
estimated 25,000 Nicaraguans, for instance, were in the United States just prior to the fall of the Somoza regime; and 30,000 Haitians have entered the United States by boat in the last fifteen years, with the 1980 flow triple that of any prior year. Recent news accounts indicate that perhaps 70,000 Salvadorans have entered the United States since the beginning of 1980, many by crossing the Mexican border. It is quite possible that in the near future the United States will experience some new flows from Cuba and Nicaragua, sudden movements of large numbers of people from Jamaica and Guatemala, and greatly increased numbers of Haitians, both from Haiti and from the Bahamas, where officials have recently attempted to repatriate many of the Haitians living there (although the Duvalier regime has been uncooperative). Increasing political tension in the region is not likely to abate soon, and unless peaceful changes in the relationship between the landed and the unlanded classes are initiated or carried further, that tension, on a country-by-country basis, is likely to explode into violence and to lead to overt persecution of all political opposition. Others, threatened by the strife, although not themselves political targets, will also flee. While any prediction is speculative, the potential thus appears to exist for an annual flow of perhaps 50,000 asylum applicants to the United States, with larger numbers arriving in years of heightened conflict.

\section{A HARD LOOK AT THE "HARd LiNE"}

The Reagan administration has not yet fully developed its response to events in this hemisphere that have the potential to affect refugee flow. Yet a "hard line" with the following characteristics appears to be emerging: confrontation, rather than negotiation, with Cuba; identification of all left-wing revolutionary trends in the region with the policies and goals of Cuba and the Soviet Union, rather than with such local concerns as land reform; extension of broad support, including stepped-up military aid, to regimes, such as those in El Salvador, Chile, and Argentina, attempting to stamp out "leftists"; isolation and destabilization of regimes, such as the one in Nicaragua, that have supported "leftists" in other countries; deemphasis of concerns about human-rights violations by regimes in power in favor of opposition to revolutionary "terrorism"; resumption of the deportation of Haitian asylum applicants illegally in the United States; interdiction by force of vessels carrying undocumented aliens to the United States; detention of asylum applicants pending resolutions of their claims; and continuation of a refusal to grant either asylum or "extended voluntary departure"-a temporary expedient used by President Carter for Nicaraguans during 1978 and 1979-to applicants from El Salvador. The primary emphasis of this emerging policy is ideological, reflecting viewpoints similar to those that were used to justify both the U.S. military intervention in the Dominican Republic in 1965 and the U.S.-supported attempt to destabilize the Allende regime in Chile in 1971. This hard-line policy will have relatively short-term, direct effects on refugee flow into the United States and the potential for indirectly affecting the volume and nature of that flow well into the future. 
The short-term effects will derive, in large part, from the Cuban government's response to the United States's more belligerent attitude toward it and from efforts of the INS to repatriate Haitians and exclude Salvadorans. In all probability, the flow of refugees from nations in the Western Hemisphere into the United States will be reduced quite substantially. At least three-quarters of all potential asylum-seekers entering the United States in 1980 were Cubans, many of whom had political reasons for leaving. Yet the large-scale sea migration could not have occurred without the Castro regime's active intervention, and clearly was manipulated for that regime's own political ends. As a result, the regime was able both to profiteer and to export some undesirable Cubans who had spent time in criminal or mental institutions and who did not meet any of the criteria of the current definition of refugee.

The Reagan administration has reportedly admonished Castro not to unleash another exodus of boat people to Florida and has demanded a commitment from Havana to take back hundreds of the undesirable Cubans who emigrated to the United States during 1980. " In its attempt to curb Cuban activities in the hemisphere, including the provision of military aid to the insurgents in $\mathrm{El}$ Salvador, the United States has threatened Cuba with a variety of reprisals, including possible military action or a naval quarantine. To date, this tough stance seems to have prevented any repetition of last year's orchestrated exodus. In marked contrast to its activities surrounding the 1980 occupation of the Peruvian embassy when the Cuban government granted almost unlimited access to embassy grounds and took no active steps to expel Cuban nationals, the Cuban government acted swiftly in February 1981 to evict aliens attempting to obtain asylum on the Ecuadoran embassy grounds. Nor was there any repetition in 1981 of the wide-spread granting of exit visas that characterized the 1980 episode.

The current treatment of Salvadorans and Haitians may discourage some of their friends or relatives from seeking to enter the United States. For potential refugees from El Salvador, the prospects appear to be for a greater, rather than a lesser, flow from that country, since Salvadoran refugees need only cross inadequately patrolled land borders to enter the United States. The number of persons displaced by fighting in El Salvador or targeted for extermination by right- and left-wing death squads has grown rapidly in the last year. U.S. pressure against Cuba and Nicaragua may decrease the flow of arms to left-wing insurgents; yet additional U.S. military aid specifically designed to help the present government to extend its control over the rugged countryside is certain to produce more refugees.

The volume of Haitian refugees seeking asylum in the United States is also likely to rise steadily. Since the summer of 1980, the situation in Haiti has worsened: Hurricane Allen further impoverished the poorest country in the hemisphere; the government's crackdown on the press and imprisonment of

1 Rowland Evans and Robert Novak, "Reagan Chooses Caribbean as Target Area," Washington Post, 25 February 1981. 
human-rights activists in late 1980 demonstrated again how deep the disregard for human rights is in Haiti; and the government's unwillingness to repatriate any of its nationals illegally in the Bahamas left some thirty thousand unwanted Haitians with no place to go. By establishing its detention program and enlisting the diplomatic support of the Haitian government in the interdiction of vessels containing Haitians, the Reagan administration has sought to counterbalance these increased migration pressures. The impact of these measures will not be determined until the spring and summer of 1982, when the weather will be most favorable for the traffic of small boats. Yet it is already clear that successful legal attacks on portions of the detention program have undercut the administration's ability to regulate the flow. The Coast Guard's presence off the coast of Haiti is minimal and is not likely to increase. Equally important, the government of Haiti has nothing to gain from cooperating enthusiastically in the repatriation of its dissidents and its poor, and the United States, given its unwillingness to undercut its allies in the ideological struggle against the "totalitarian" left, lacks a credible "tough" response to force such cooperation.

Even if the United States currently possessed the means to exclude Haitian or Salvadoran refugees as effectively as it may be able to exclude Cubans, it is doubtful in the long run whether such exclusion either could be maintained or would prove beneficial. Barriers to entry will be only partially effective, particularly along the porous Mexican border, and the cost of a gunboat diplomacy to keep that flow away from U.S. shores may be prohibitive, not only in dollars and cents, but also in terms of maintaining good relationships with other "receiver" or "conduit" nations and of upholding the country's international reputation generally. ${ }^{12}$ Under these circumstances, pressures to limit the entry of refugees will always be competing with, and sometimes be outweighed by, international pressures. Such pressure will frequently be intensified by strongly voiced domestic sentiment for the admission of particular groups of refugees who appeal to the humanitarian or ethnic sensibilities of certain segments of the U.S. population.

For these reasons, unless the U.S. government addresses refugee-producing situations directly, it will grow increasingly difficult to exclude asylum-seekers, not only those coming from El Salvador and Haiti, but also from other countries in the region. It is probable that among these asylum-seekers will be a substantial number of Cubans. Current governmental responses to the Castro regime may have stemmed the tide, but cannot be expected to hold it back indefinitely. It is hardly accidental that the United States resettled over 900,000 Cubans in the first twenty years of Castro's rule. Geographical proximity, a

\footnotetext{
12 According to the Government Accounting Office (GAO), it would require "an increase of $\$ 125$ million in the [INS] $\$ 250$ million annual operating costs" to obtain the personnel, fencing, helicopters, and so forth, necessary "to secure about 10 percent of the 2,000-mile Mexican border" (Comptroller General of the United States, Prospects Dim for Effectively Enforcing Immigration Laws: Report to the Congress of the United States [Washington, D.C.: GAO, 1980], p. iii). Moreover, the President's Task Force on Immigration and Refugee Policy estimates that an 85 percent effective interdiction program by the Coast Guard would cost $\$ 425$ million annually.
} 
large and vocal Cuban community in the United States, periodic economic distress in Cuba, and genuine opposition to Castro's brand of communism, both here and in Cuba, are all factors promoting refugee flow. The Reagan administration's "hard line" is predicated in part on an antidétente strategy that permits rough treatment of the Soviet Union's client state and in part on a perception of regional politics that believes the United States can take a strong stance on Cuba without endangering relationships with countries in the hemisphere who have been traditional allies. Global political considerations may require another East-West "thaw," or otherwise militate against making Cuba a confrontation point with the Soviet Union. State Department personnel have already voiced concern that the current administration's anti-Castro campaign may backfire by provoking another mass exodus, which the United States will be powerless to prevent. ${ }^{13}$ If recent Mexican and Venezuelan responses to current U.S. Cuban policy are at all indicative of relationships between the United States and other countries in the hemisphere, then strong regional reasons already exist for the United States to modify its stance. Thus, global and regional factors may well combine to deprive the United States of much of the leverage it has against Castro and force it to seek other methods of limiting refugee flow.

\section{Human Rights and an Effective Admissions Policy}

In the long run the only effective way of reducing the flow of refugees to the United States from countries in this hemisphere is to address concretely the conditions that create refugees. To do so the United States will have to maintain a foreign policy that raises the issue of persecution abroad, provides the means to at least partially reduce the political and economic tensions that lead to such persecution, and takes concrete nonmilitary action against those nations that persist in persecuting their own citizens.

To date, the Reagan administration's approach to persecution abroad has not deterred refugee flow to the United States. President Reagan and Secretary of State Alexander Haig have given priority to strengthening the United States's resolve and resources to defend allies the administration considers threatened by totalitarian aggression or subversion. The White House has expressed its belief that by exercising U.S. power, deterring war, and preventing the expansion of Communist rule, they are protecting such basic international human rights as freedom from foreign domination, internal security, and the freedom of person. The administration's relationship with the governments of Guatemala, Haiti, Argentina, and Chile in this hemisphere, as well as with the governments of South Korea and the Philippines, falls within this framework. Aid to such regimes, including the provision of weapons that can be used against domestic dissidents, is regarded as good public policy. For this reason, President Reagan

${ }^{13}$ Barbara Crossette, "U.S. Diplomats in Cuba Dissent on Radio Plan," New York Times, 29 October 1981. 
fought - unsuccessfully - to prevent any tie-in between the human-rights situation in El Salvador and U.S. military assistance. ${ }^{14} \mathrm{~A}$ recent memorandum by former Deputy Secretary of State William Clark and approved by Secretary Haig commits the administration to "acknowledg[ing]" and "oppos[ing]" all violations of human rights, whether perpetuated by friends or by foes. ${ }^{15}$ Yet the administration has not, to date at least, taken concrete action in support of such a commitment. And as military governments get the message that the democratization process supported by the Carter administration can slow down, it seems certain that refugee flow to the United States will increase.

It is necessary, therefore, that the United States develop bilateral and multilateral arrangements that better address and alleviate the conditions that create refugees. In particular, the United States should pursue a set of foreignpolicy objectives designed, first, to open lines of communication with sender nations; second, to discourage the practice of persecution in these nations; and third, to convince these nations that it is not in their best interest internationally to expel undesirables and political opponents, including those who are not genuine refugees.

\section{Bilateral Diplomacy}

Without direct and continuous communication, the means of influencing countries in this hemisphere to stop either persecuting dissidents or expelling undesirables, or both, is decidedly limited. It seemed an article of faith of the Carter administration that the United States was "stuck" with all of the recent boat people from Cuba, nonrefugees as well as refugees, because Castro was totally unwilling to take any of them back. As things stand at present, such a belief is probably justified. Yet the United States's attempts to isolate Cuba diplomatically and economically over the last twenty years have certainly been major factors contributing to America's current limited diplomatic leverage with Castro. By pursuing a policy favoring confrontation rather than compromise, the United States has encouraged unilateral activity on Castro's part, some of which reflects long-standing political antagonisms. Adverse effects of this activity in the United States frequently have been compounded because the closing of direct diplomatic channels has had as one of its results the denial of intelligence information to American planners. The recent Cuban migration was unexpected; if further migration occurs, its magnitude is likely to remain a mystery until the last boat docks.

Full and adequate diplomatic relations with Cuba are likely to provide a firmer and more satisfactory basis for reaching an accommodation with the Castro regime than the current hard line ever can. This fact was apparently

\footnotetext{
${ }^{14}$ See "Reagan Plan Rejected: Senate Votes Terms for Salvadoran Aid," Washington Post, 25 September 1981.

is "Excerpts from State Department Memo on Human Rights," New York Times, 5 November 1981.
} 
recognized by the Carter administration, which attempted during its first years in office to secure a better diplomatic modus vivendi with the Castro regime than had existed since 1959. The failure of that effort, which anticipated by only a few months the onset of the 1980 Cuban boatlift, does not detract from the importance of the goal. Normalized relationships between the two countries will give the United States the opportunity to enter into direct negotiations with Cuba concerning the status of Cuban prisoners and mental defectives currently confined in American institutions. Such improved relations will also permit the United States to explain more clearly its concerns about unregulated refugee flow and the conditions that promote it and will have the added advantage of providing the kinds of information required to predict problems before they become insurmountable. Normalized relations will also provide a better, less inherently threatening way of raising the issue of human-rights violations that create refugees than is possible through other vehicles, such as the propaganda broadcasts that the Reagan administration currently plans to beam into Cuba. Similarly, it must be the goal of the United States government to maintain full and adequate diplomatic relationships with every nation in Central America and the Caribbean, whatever their political tendencies, since each has the potential either to send refugees seeking asylum to the United States or to act as a conduit during periods of economic or political upheaval.

\section{Bilateral and Multilateral Development Assistance}

A point that is too seldom emphasized is the indirect nature of the relationship between the level and type of development assistance and the expansion or contraction of refugee flow. For example, money given or lent to Haiti to build roads or irrigate farms is not the equivalent of money used to purchase food or shelter or medical supplies for those fleeing from persecution in Ethiopia or Cambodia. In the latter instance, the expected benefit, although frequently substantial, is short term: to give temporary aid to starving, homeless, diseased people; if these people are placed in refugee camps, those camps are not selfsustaining, and the aid must be constantly renewed. In contrast, the expected benefit of development assistance is characteristically long term, and positive results may not begin to emerge until long after the money is spent: for example, the road in Haiti may remain unused until a cement plant is built at its terminal point.

Associated with the short-term nature of refugee relief are fairly immediate indicators of success, which are closely tied to the results of persecution or want. Thus, relief aid can be deemed successful if people no longer starve, have a roof over their heads, and no longer contract various diseases in large numbers. Measuring the success of development assistance is always difficult. It becomes even more so when such assistance is linked to policy expectations in the humanrights and refugee areas.

The lack of a direct, general relationship between development assistance and 
persecution does not mean, however, that all types of assistance are equally likely to be used for persecution as for nonpersecutive ends. For example, military aid, especially programs directed to support police or internal security forces of repressive regimes, is liable to be used to suppress dissent. Nonmilitary aid directed to traditional holders of power and wealth may "trickle down" to farmers and laborers, slowly bettering their standard of living, but actually widening the disparity between the living conditions of the rich and the poor. In the long run, such aid is likely to exacerbate rather than alleviate the tensions between the haves and have-nots, and thus, make persecution more, rather than less, likely. Nonmilitary aid directed toward the disadvantaged is likely to offend traditional elites and thus could trigger repression. Yet in the long run, it is only this type of aid that is likely to defuse the explosive mix of privilege and poverty endemic in so many countries of the Caribbean and Central America. Periodically ignited by political events common to the region, such as the spread of Castro's theories of social revolution, or specific to a particular country, such as the assassination in January 1978 of Nicaragua's leading opposition spokesman, that mix, unless reformulated, will continue to produce refugees who are victimized by recurrent waves of repression and thus are anxious to come to the United States.

Development assistance directed toward the poor of the region can therefore serve a significant, although indirect, role in eventually reducing refugee flow. Yet because the effect of such aid is indirect, and thus may take a number of years to unfold fully, such programs as are developed with the objective of reducing the flow of refugees should be given ample opportunity to work before being curtailed or terminated. Because it is clear that the United States lacks the resources to finance sweeping social changes throughout the Caribbean and Central America, it should choose its target countries carefully, focusing most of its attention on nations that are either already refugee senders or likely to become so. U.S. policymakers should also make a special effort to promote social reform at the grass-roots level in Haiti and Jamaica, both of which are likely to be significant refugee senders in the 1980s.

For many of the same considerations that warrant the "targeting" of bilateral development assistance, the United States should also become more heavily involved in multilateral development programs than it has in the recent past. The Reagan administration's approach to date is highly equivocal. On one hand, it has offered increased economic assistance to the government of El Salvador and joined in the multilateral North-South dialogue initiated at the Cancun conference held on 22-23 October 1981. Yet at that conference, Reagan made no pledge to a new international aid program, much less to the "New International Economic Order" favored by the poorer participating nations. The present administration has also reached an understanding with Mexico and Venezuela to cooperate in devising aid programs for the nations of the Western Hemisphere. The only aid contemplated by the administration, however, appears to be loan guarantees that, among other things, will enable U.S. businesses to expand their markets throughout the region. 
It is through lending agencies such as the World Bank and through regional development institutions that the appropriate type and level of aid can best be initiated, and the cost and risks associated with such aid best distributed. Although these institutions are hardly apolitical, they can be expected to put greater emphasis on long-term development goals than on short-term trade advantages to the lender. Linking these development goals to current concerns about human rights in desperately poor countries such as Haiti, however, is likely to prove as difficult for international assistance authorities as it is for the United States Congress. Clearly, recipient nations must not only meet requirements for financial accountability, they must also give reasonable assurances that this assistance will not be used to strengthen their repressive capabilities. Yet properly designed and monitored aid programs can both contribute very materially to the economic and social well-being of a population and substantially strengthen ground-level participatory institutions despite efforts of a repressive regime to misuse them.

\section{Bilateral Military Assistance}

Perhaps the most obvious source of bilateral leverage is with regard to U.S. military assistance. In general, the United States should seek to dissociate itself from repression by denying exports of arms, munitions, and military or police equipment to the military or police forces in countries where human rights are known to be violated or where the record is questionable. Such sanctions are already required by U.S. law; yet such legislation has been applied inconsistently, particularly in cases where other U.S. interests such as the regional balance of power, U.S. base rights, and continued constructive bilateral relations are perceived to be at stake.

Many of the countries in this hemisphere have a long tradition of military rule, sometimes only intermittently replaced by more democratic forms of government. Individuals such as Pinochet, Batista, Trujillo, and the Somozas have all demonstrated how the military can be turned into an instrument of systematic persecution. Thus, military power in all of Latin America, although sometimes relatively benign, has the potential to be used, not to counter external threats, but to repress internal dissent. The recent spread of terrorism, in some instances clearly supported from abroad, has tended to obscure the boundary between the two. As recent events in Argentina, El Salvador, and Guatemala illustrate, the military reaction to such terrorism, however much it may be motivated by fears of Marxist revolution, can seriously and systematically undermine political and other human rights and help create large numbers of potential refugees.

Military dictatorships will continue to seize power in Latin America and they will continue to exercise that power according to their own political views whether or not the United States provides military assistance. Yet the scope of that power, and the regimes' ability to use it directly against domestic dissidents, will often depend on the amount and nature of U.S. military assistance being 
received. In general, U.S. programs that support police or internal security forces of repressive regimes contribute to the capacity of -and serve to legitimize the efforts of - those regimes to control and suppress dissent. Despite recent efforts made by the Congress to curb U.S. military assistance to repressive regimes, undemocratic leaders such as Anastasio Somoza of Nicaragua and the Shah of Iran were able to purchase unlimited quantities of gas masks, gas riot grenades, and riot control munitions through the U.S. Commercial Sales program to maintain power and repress political dissent right up to the closing days of their rule. It was not lack of weapons, but rather internal discord and disregard of basic rights, that brought about the downfall of both men.

Renewed U.S. concern with what it perceives as traditional threats to its national security may create a political environment in Latin America in which human rights and anticommunism are seen as synonymous. To regard events in Central America and the Caribbean primarily in terms of minimizing Soviet and Cuban influence is to pay little heed to local political factors and to look upon conflicts in the Third World as abstract units in a global contest for military power. Such an approach to regional problems presages a return to the position the United States took during the post-World War II years when, in the name of the unity of the "free world," successive American administrations recruited and embraced regimes of the authoritarian right in the effort to contain the totalitarian left.

Military support for repressive and unpopular regimes is bad foreign policy because such regimes cannot stand on their own when internal and external pressures mount. Such regimes almost inevitably produce large numbers of refugees. It is important, therefore, that U.S. assistance not directly or indirectly strengthen the repressive capabilities of the governments of Latin America. Future proposals for transfers of military and security items should be scrutinized with great care to determine if their use would contribute to the repressive functions of official or unofficial internal security forces.

\section{Multilateral Pressures on Sender Nations}

More cooperation among nations receiving refugees, through new multilateral arrangements or through existing regional and world organizations, is both possible and advisable. Yet a key element of an effective asylum policy must be the recognition that there is no magical "international" solution to the problem of uncontrolled refugee flow. Areas in which international cooperation is likely to prove most effective include the creation, funding, and implementation of development assistance programs and the exertion of concerted pressure on countries that are expelling their undesirables or persecuting their citizenry. It is unlikely, however, that other nations or international agencies could play a significant role in helping to screen and resettle refugees and other asylum applicants seeking admission to the United States. Nonetheless, national govern- 
ments and international agencies should actively explore ways to effect better arrangements for channeling and distributing the future flow of refugees.

The United Nations meeting on Refugees and Displaced Persons, held in Geneva on 20-22 July 1979, provides a valuable example of the possibilities - and pitfalls - of international attempts to influence the behavior of sending nations. The primary topic addressed at that meeting concerned the problems posed by the massive outflow of refugees from Vietnam, Cambodia, and Laos into neighboring countries. The sixty-five countries in attendance pledged resettlement aid totaling some $\$ 160$ million, and several governments increased their resettlement commitments, raising the total number of placements from 125,000 to 260,000 . Conference members also planned a new processing center in the Philippines and pledged international cooperation in effecting sea rescues.

The attending nations also gave a "general endorsement" to the principles of asylum and non-refoulement (forcible return) set forth in the 1951 Convention Relating to the Status of Refugees, the 1967 Protocol Relating to the Status of Refugees, and the 1967 Declaration on Territorial Asylum, apparently to emphasize their concern about threats to turn refugee boats back to their country of origin and the manner by which the Thai government summarily repatriated some 50,000 Cambodians. Conference members more than offset this weak concern for the rights of refugees to leave their country of origin, however, by expressing a strong desire to reduce refugee flow, a desire that resulted in an announcement that Vietnam "for a reasonable period of time. . .will make every effort to stop illegal departures."16 That announcement contained neither a general condemnation of Vietnamese persecution of ethnic Chinese nor a reassertion of the principles of Article 13(2) of the Universal Declaration of Human Rights, which ensures freedom of travel. Therefore, although significant positive steps were taken to alleviate the plight of existing refugees, the final results of the 1979 Geneva meeting were, at best, mixed. Practical control of a difficult situation was obtained only by undercutting the basic philosophical commitment of the United Nations to guarantee to peoples facing persecution the freedom to move out of danger.

There are obvious parallels between recent events in this hemisphere and those that prompted the Geneva meeting: the large-scale movements of refugees by land and sea into neighboring territories; the consequent use of force to intercept emigrant vessels; the detention of asylum-seekers in harsh holding camps; and the summary repatriation of the refugees to their homelands with only a minimum of due process. Clearly, the time has come to reassert the principles of asylum and non-refoulement. In addition, the recent expulsion of large

\footnotetext{
16 "Statement of the Secretary General at the Opening of Meeting on Refugees and Displaced Persons," United Nations Press Release, Department of Public Information, 20 July 1979, cited in "Refugees - United Nations Meeting on Refugees and Displaced Persons in Southeast Asia, July 20-21, 1979," Harvard International Law Journal 21 (Winter 1980):292.
} 
numbers of Cuban undesirables to the United States bears an uncanny resemblance to the conduct of the Vietnamese toward ethnic Chinese. Thus, there is strong justification for a coordinated effort among nations of the Western Hemisphere to bring concerted regional pressure against Castro in order to avoid such conduct in the future.

Yet a conference on refugees and displaced persons can do a great deal of harm if those in attendance avoid the difficult issue of human-rights violations in the country of origin and choose to approach the refugee problem, not by seeking to minimize persecution, but by diligently finding more efficient ways to cut off avenues of escape. Any international attempt to control the expulsion of undesirables by a country should keep two principles firmly in mind: "orderly departure" is a permissible goal, but ought not be confused with denying all egress to those who are in fact refugees; and it is essential to determine which individuals being expelled are in fact refugees and which are common criminals, or are mentally impaired, or are otherwise social misfits.

\section{Multilateral Refugee Aid and Resettlement}

In order to deal adequately with increased refugee flow in this hemisphere, it is essential that multilateral aid be made available to other countries in the region that serve as countries of first asylum and, in many instances, as conduits to the United States. Failure to provide aid to the thousands of Salvadorans and Guatemalans streaming across Mexico's southern border will encourage additional migration farther north. Although neither the Bahamas nor the United States, except perhaps in the most extraordinary circumstances, is currently willing to regard Haitians as refugees, it appears that many of those now fleeing Haiti could fall within the mandate of the Office of the United Nations High Commissioner for Refugees (UNHCR). Consideration should be given to the establishment of an international refugee aid program in the Bahamas. Such a program could pave the way for a more humanitarian evaluation of the Haitian situation in the financially overburdened Bahamas and could ultimately slow the flow of refugees to the United States.

To the fullest extent possible, efforts should also be made to share the burden of resettling refugees, particularly those in the Western Hemisphere. The recent record, however, is not very encouraging. When some 10,000 Cubans occupied the Peruvian embassy grounds in April 1980, efforts were made to resettle them. The plan initially had called for nearly all the refugees to go to Costa Rica, but before the airlift to Costa Rica ceased to function, the United States promised to take in 3,500 Cubans; Peru said it would accept 1,000; and Costa Rica, Spain, Ecuador, Argentina, Canada, and Belgium offered homes to another 1,750; this left several thousand Cubans with no place to go.

The subsequent mass migration of Cubans, beginning in April of 1980, had as its exclusive object resettlement in the United States. Migration of Haitian boat people to the United States began in the 1960s and has periodically increased in 
volume. Unlike recent Cuban migration, however, the movement of Haitians to the United States as potential asylum-seekers has been part of a larger migration that has long-standing economic origins and that has sent sizable numbers of Haitians to various countries in the Caribbean and North America. Thus, although the opportunities for legal emigration are limited, hundreds of thousands of Haitians have left Haiti, often without any documentation, to seek work in the Bahamas, Canada, and the United States. Perhaps a million others have crossed the land border into the Dominican Republic to seek employment. The actual Haitian migration to the United States is undoubtedly much greater than that involving the boat people arriving in southern Florida. Yet it is only a small portion of the actual migration of Haitians generally, and its volume depends heavily on the Haitian refugees reception in other countries. Thus, whenever the Bahamian government has threatened to "crack down" on its illegal Haitian population and has begun repatriating Haitians, Haitian boat people have arrived in the United States in much greater numbers.

These migration patterns have significance well beyond their historical interest. Although a substantial number of Cubans fled to Spain and Mexico during the early years of the Castro era, the United States, only ninety miles away - and with its massive Cuban community in Miami, its former colonial ties, and its twenty-year history of receiving refugees-has become, in the region's eyes, the most natural recipient of Cuban refugees. The recent unmanageable level of Cuban flow gave the United States good reason to seek international assistance, but it did not give other countries in the region good reason to assume a larger share of refugee resettlement responsibilities. Future large-scale migration of Haitians, should it occur, stands on a somewhat different footing. The United States will have stronger grounds for insisting on a more equitable sharing of resettlement responsibilities among countries with geographical, historical, and linguistic ties to Haiti. Similarly, arguments for shared responsibilities will be stronger when dealing with applicants from other countries in the region who have identifiable ties to countries other than the United States.

Steps should be taken now, however, before the next refugee crisis begins, to determine the depth of commitment that particular countries in the region have to their neighbors. To the fullest degree possible such commitments should be intensified by bringing other countries into the planning and implementation of development assistance programs targeted on probable sender nations and by developing aid programs specifically keyed to the problems of other receiver nations. Steps should also be taken now to establish a program for screening refugee applicants either in their country of origin or in some other locality not likely to be chosen as a country of final asylum. In this way, it will be possible to distribute refugees among various countries according to some mutually agreeable plan without necessitating overly extensive involvement by chosen countries of final asylum.

Even if a means of processing refugees in their country of origin, or at some 
third-country holding center, is developed, it is unlikely that the individual countries receiving applications will choose to surrender their power to determine the bona fides of particular claims to a collective body. This is not to say that actual processing may not be affected by decisions reached through multilateral negotiations or that UNHCR determinations may not be afforded great weight. Actual screening by the United States may well prove to be a formality in many cases. Yet the same political considerations that favor recommending that new U.S. asylum procedures give the UNHCR only an observor's role-namely, that domestic sentiment appears strongly to favor the maintenance of direct governmental control of refugee admissions - apply with even greater force to out-of-country applicants.

Control of applicants for mass asylum will continue to pose difficult political and moral choices for the United States. These difficult choices are not going to disappear soon, but they can be alleviated somewhat if the nation pursues a vigorous foreign policy designed to minimize persecution abroad, particularly in the Western Hemisphere. The primary focus must be on the reduction of refugee flow by eliminating "well-founded fear," rather than on an orchestrated international blindness to those facing imprisonment, torture, or death simply because they belong to the wrong profession or because they happen to express contrary political views. 